Check for updates

The BMJ

Cite this as: $B M J 2022 ; 376: 0335$ http://dx.doi.org/10.1136/bmj.0335 Published: 07 February 2022

\section{Covid-19: Only a third of children in need accessed mental health support in the pandemic}

\author{
Ingrid Torjesen
}

The number of children experiencing mental health problems has risen sharply during the covid-19 pandemic, but fewer have been able to access support because of disruptions to services, says a report by the children's commissioner for England. ${ }^{1}$

Around one in nine children had a probable mental health disorder in 2017, the report says, but this jumped to one in six in 2021 with only around a third $(32 \%)$ able to access treatment.

While the number of children referred to mental health services by GPs and teachers has been growing in recent years, referral rates fell back in 2020-21 to 497502 (equivalent to 4\% of all children in England), compared with 539000 ( $4.5 \%$ of children) the previous year.

"It is likely that even though more children have mental health problems, fewer were being referred to services during lockdowns because of disruptions caused by the pandemic," said children's commissioner for England, Rachel de Souza.

"Numbers referred into services are likely to increase again in the coming years. The health secretary will be publishing a review later this year to explore how we can tackle this increased level of need and adopt a more preventive approach."

Spending by the NHS on children's mental health increased by $4.4 \%$ in real terms in 2020-21 compared with 2019-20, and for children accepted for treatment, average waiting times fell from 43 days in 2019-20 to 32 days in 2020-21.

Over a third (37\%) of children accepted onto waiting lists are still waiting for their treatment to begin, however, and this proportion varies widely between clinical commissioning groups (CCGs)-from as low as $14 \%$ in NHS Castle Point and Rochford and NHS Mid Essex to $78 \%$ in NHS East Sussex.

Spending on mental health for each child in 2020-21 also varied from a high of $€ 165$ a child by NHS Isle of Wight CCG to a low of $€ 16$ a child by NHS Halton.

The proportion of children whose referrals were closed before starting treatment decreased from $36 \%$ to $24 \%$ between 2018 and 19 and $2020-21$, but again there were wide variations between CCGs with closure before treatment ranging from $8 \%$ of referrals in NHS East Sussex, NHS Liverpool, and NHS Leeds to $41 \%$ in NHS East and North Hertfordshire, NHS East Riding of Yorkshire, and NHS Barnsley.

"As a society we need to raise our level of ambition to support children's mental health,” de Souza said. "This means schools and early years settings providing good support for all their children. It means mental health support teams in schools being extended across the country. It also means a continued push to increase access to NHS services."

Lynn Perry, interim co-chief executive of children's charity Barnardo's, said, "Covid-19 has taken a serious toll on children's mental health and schools are the first place many of them seek help. Being able to reach this support early at school will reduce the number of children who need specialist help from mental health services. This is why Barnardo's is calling on the government to speed up the rollout of mental health support teams to help pupils and teachers get the support they need, when they need it.”

1 Children's Commissioner for England. Children's mental health services 2020-21. February 2022. www. childrenscommissioner.gov.uk/wp-content/uploads/2022/02/cco-briefing-mental-health-services-2021-22.pdf

This article is made freely available for personal use in accordance with BMJ's website terms and conditions for the duration of the covid-19 pandemic or unti otherwise determined by BMJ. You may download and print the article for any lawful, non-commercial purpose (including text and data mining) provided that all copyright notices and trade marks are retained. 